\title{
Gandhi in the Tropics: Climate, Disease and Medicine
}

Bikash Sarma is a Faculty with the Department of Political Science, Salesian College, Siliguri.

The paper draws on a historiography of medicine in India and Gandhi's engagement with it through a process of qualitative denunciation and qualitative appreciation. To position western medicine in the context of India requires an elaborate historiography underlining a series of knowledge production about the land the colonizer encountered and their constantly changing perception about the landscape, climate, disease and the natives at the contact zone. The paper would attempt to locate the emergence of the discourse on medicine within these changing perceptions of the colonizer and to position Gandhi within this emerging discourse.

Key words: Gandhi, medicine, tropics, climate, disease.

\section{Introduction}

One way to approach colonial encounter is to understand it as a process of representations and geographical imaginations. These representations and imaginations were informed by a form 'knowing' of the colonizer - what is already known and what was experienced and seen at these contact zones. The "contact zones" as Mary Louise Pratt argues are "social spaces where disparate cultures meet, clash, and grapple with each other." ${ }^{1}$ These were also spaces of asymmetrical exchanges between the colonizer and the colonized and it is here the presumed differences between the west and the rest became manifested in different forms.

This mode of producing difference was possible through a series of representations enacted by numerous agents of the colonial state. Colonial expeditions produced the real as, to borrow from Heidegger, "a standing reserve". The colonial descriptions were an act of ordering "to stand by, to be immediately at hand, indeed to stand there just so that it may be on

1 Mary Louise Pratt, Imperial Eyes: Travel Writing and Transculturation, (London: Routledge,1992), 4. 


\section{2 / Bikash Sarma}

Salesian Journal of Humanities and Social Sciences, Vol. X, No. 2 (Dec 2019)

ISSN: 0976-1861 | 10.51818/SJHSS.10.2019.71-81 | Page: 71-81,

Section: Articles

call for a further ordering." ${ }^{2}$ The modern subject of the west is thought to have 'emancipated' herself from mysterious nature and is entrusted to discover the real through multiple 'rational' practices and performances. "Enframing" enables a discourse of domination of the 'errant universe' of the colonized - both humans and non-humans clubbed together by placing them at the bottom of the hierarchy. Modern enframing of nature and colonial representations both have the same terminus and are "coercive, invasive, appropriative...it makes nature available for inspection, codification, calculation, and regulation. ${ }^{3}$ Enframing not only enabled a domination of the unruly nature but also the savage child of this unruly nature. For the Europeans, their cultural practices transcended the nature and its caprice creating a chronological gap between nature and culture. And all other societies are conditioned by nature alone - 'savages' or the 'children of mother earth'.

This colonial modernity as expressed through subjugation of nature that calls for destroying and separating the unity of human and nonhumans. With the destruction of the unity and as a result of the binary created between humans and non-humans an unprecedented violence is unleashed against this nature. Nature's resources were "ruthlessly exploited and its rhythm and balance disturbed, and animals were freely killed or tortured for food, sport, fancy clothes, and medical experiments. In Gandhi's view violence 'oozed from every pore' of modern society," ${ }^{4}$ and gradually became all pervasive in the life of people.

Colonial modernity in India was decidedly a geographical project that created difference and a desire to order these produced differences. Every aspect of climate, vegetation, land, water, and the characteristics of the natives played a role in the geographical project of creating an "antipodal

${ }^{2}$ Martin Heidegger, The Question Concerning Technology and Other Essays,(New York: Garland Publishing,1954), 17.

${ }^{3}$ Derek Gregory, "Post (colonialism) and the Production of Nature", in N. Castree and B. Barun (ed.)Social Nature: Theory, Practice, and Politics, (Oxford: Blackwell, 2001).

4 Bhikhu Parekh, Gandhi's Political Philosophy: A Critical Examination,(London: Palgrave,1989), 25. 
Gandhi in the Tropics: Climate, Disease and Medicine / 73

Salesian Journal of Humanities and Social Sciences, Vol. X, No. 2 (Dec 2019)

ISSN: 0976-1861 | 10.51818/SJHSS.10.2019.71-81 | Page: 71-81,

Section: Articles

division" ${ }^{5}$ of the world between England and the Tropics. Meteorological understanding of disease in the nineteenth century became an extension of this geographical project. The epidemiological figured prominently within this colonial project of medicine and sanitation.

The idea of India started with statements of "idealization." Exuberant tropical nature and primitiveness of its people as a 'child of mother earth' gradually transformed into statements about diseases and miasma of tropical jungles and indolence and degeneration of the natives. So the paradise turned into ferocity and degeneration. Stuart Hall summarizes the discursive strategies of othering into the phases of idealization followed by projection of fantasies, failure to recognize and respect difference and to see difference through mode of perception of the west by imposing European categories. ${ }^{6}$ A tropic in that sense is a hierarchal positionality of delimiting and demarcating between the East and the West.

Environmental determinism remained a dominant paradigm not only as cause of diseases prevalent but also to ascribe on to the natives as the cause of degeneracy, effeminacy and indolence. Their inability to understand the cause of diseases perpetuated it. This dominant paradigm to understand diseases thought to be caused by 'tropical' climate was supplemented by enumerated social and cultural practices of the natives. Along with climate, race, health and medicine formed the core of an assertive idea of imperial expansion and domination and to certain extent hegemony.

The outbreak of a series of epidemics in the nineteenth century further accentuated an epidemiological difference with the tropics. Climate and now epidemics thought to be a threat to the European constitution in the tropics. Not only that, western medicine and science acquired a new meaning in the tropics. It was based on the landscape of disease as well as moral and cultural landscapes. Western medicine and science for the

\footnotetext{
${ }^{5}$ Harish Naraindas, "Poisons, Putrescence, and the Weather: Genealogy of the Advent of Tropical Medicine", Contributions to Indian Sociology 30,1(1996): 32.

${ }^{6}$ Stuart Hall, "The West and the Rest: Discourse and Power", In Formations of Modernity, (Cambridge: Polity Press,1992), 215.
} 


\section{4 / Bikash Sarma}

Salesian Journal of Humanities and Social Sciences, Vol. X, No. 2 (Dec 2019) ISSN: 0976-1861 | 10.51818/SJHSS.10.2019.71-81 | Page: 71-81,

Section: Articles

colonizer came as a rescue to tame wild tropical nature and also to control epidemic diseases, however, often met with failures in case of the latter. Towards the second half of the nineteenth century a number of discourses proliferated on sanitation, quarantine, hygiene, architecture and a series of movements connected with these 'moral meteorologies. ${ }^{7}$

This concern of the colonial state was reflected in the rise of medical literature in the nineteenth century and the emergence of a series of medico-topographical surveys that started with Francis Buchanan who was assigned the task in 1807 to conduct a survey in eastern India. ${ }^{8}$ In subsequent years this volume of literature increased and these medicotopographical surveys constituted one of the chief sources of knowledge about health, hygiene and disease.

\section{Colonized bodies: Gandhi and Medicine}

Gandhi metaphorically represented the 'body politic' under colonialism with that of the human body. Indian body politic has become so weak and diseased to resist foreign rule as that of the human body to resist desires and indulgence that is accentuated by medicine in general and colonial medicine in particular. ${ }^{9}$ Gandhi's emphasis on health, sanitation could also be translated as a contestation over the colonized bodies. Gandhi still expressed optimism that the human soul can escape the 'deadly knife' of the surgeons. In a lecture delivered at Ashtanga Ayurveda Vidyalaya in 1925 he said: "Little do they know that soul survives the knife and that the soul is not to be found in any probing of knife, however, deep it may be" $^{\prime 10}$

However, Gandhi's engagement with the discourse of different variants of medicine and its effects on the colonized body calls for an understanding

\footnotetext{
${ }^{7}$ Harish Naraiandas, "Poisons, Putrescence and the Weather", Contributions to Indian Sociology 30: 1-35.

${ }^{8}$ David Arnold, Colonizing the Body: State Medicine and Epidemic Disease in NineteenthCentury India, (Berkley: University of California Press, 1993), 25.

${ }^{9}$ Parekh Cited in Arnold, Colonizing Body, 285.

${ }^{10}$ Gandhi, Collected Works, vol. 27, 45.
} 
Gandhi in the Tropics: Climate, Disease and Medicine / 75

Salesian Journal of Humanities and Social Sciences, Vol. X, No. 2 (Dec 2019)

ISSN: 0976-1861 | 10.51818/SJHSS.10.2019.71-81 | Page: 71-81,

Section: Articles

of his qualified denunciation and qualified appreciation of the former. The dictum of experience forms the core of Gandhi's apprehension about modernity and medicine both western and indigenous. His experiential thought occupies this liminal space between modern and anti-modern; western medicine and indigenous medicine. This liminal space of his thought in turn is mediated by everyday experiences with a constant flow and of not being trapped by any categorical determinism. Gandhi's understanding of medicine appears to be contradictory but is mutually constitutive. Knowing well aware of these inconsistencies he in a letter to Kalishankar Chakravarti wrote:

Where you find contradictions in my writings, I find nothing but a due fulfillment or elaboration of a previous position. But I am not so much concerned with showing consistency in my writing as with stating that I have given to the readers the truth as I have known at the time of writing. ${ }^{11}$

In a different account he further writes:

I have never made a fetish of consistency. I am a votary of truth and I must say what I feel and think at a given moment on question... ${ }^{12}$

However, this method of approaching medicine in the context of the body is also ethical. Further, a careful reading of Gandhi - underlining this method concerning the discourse on medicine - would enable one to move beyond fixing Gandhi on an either/or category and to understand the divergences and reflexivity conforming to his everyday experiences.

Gandhi elaborated modern system with a metaphor of Upas tree in Hind Swaraj, as he contends:

Its branches are by parasitical professions, including those, of law and medicine...Immorality is the root of the tree...I was at time a great lover of medical profession. It was my intention to become a great doctor for the sake of the country. I no longer hold that opinion. I now understand why the medicine men among us have not occupied a very honourable status. ${ }^{13}$

${ }^{11}$ Gandhi, Collected Works, vol. 59, 55-56.

${ }^{12}$ Gandhi, Collected Works, vol. 65, 62.

${ }^{13}$ Gandhi, Hind Swaraj, (New Delhi: Rajpal Publications, 2009), 77. 


\section{6 / Bikash Sarma}

Salesian Journal of Humanities and Social Sciences, Vol. X, No. 2 (Dec 2019) ISSN: 0976-1861 | 10.51818/SJHSS.10.2019.71-81 | Page: 71-81,

Section: Articles

His change of opinion about the medical profession can be traced to an intervention by his family. That happened after his matriculation (1887) when Mavji Dave, an old friend and adviser to the Gandhi family was in discussion with Gandhi's mother and brother about his career, among other things. Mavji Dave wanted Gandhi to be sent off to England to pursue his professional studies. Gandhi immediately 'jumped at the proposal' and expressed his desire to pursue a medical profession but his brother interrupted and said:

Father never liked it. He had you in mind when he said that we Vaishnavas should have nothing to do with dissection of dead bodies. ${ }^{14}$

In fact Mavji insisted that Gandhi should become a barrister as a medical degree would not make him a Diwan. ${ }^{15}$

The discussion from the Gandhi family also reflects on the professional career opportunities as the educated Indians perceived in the nineteenth century colonial India. As David Arnold argues:

Medicine had been far less successful in this regard than the legal profession which, with a minimum of state sponsorship and regulation, had flourished like a hothouse plant in the steamily litigious atmosphere of colonial India. ${ }^{16}$

For Gandhi the medical discourse that was already penetrating into Indian society was essentially manifestation of colonialism over the body and the mind. As he articulated:

The English have certainly effectively used the medical profession for holding us. English physicians are known to have used their profession with several Asiatic potentates for political gain. ${ }^{17}$

${ }^{14}$ Gandhi, An Autobiography: The Story of My Experiments with Truths, (New Delhi: Fingerprint Publishing, 2009), 47.

${ }^{15}$ Gandhi, An Autobiography, 47.

${ }^{16}$ Arnold, Colonizing Body, 3.

${ }^{17}$ Gandhi, Hind Swaraj, 77. 
Gandhi in the Tropics: Climate, Disease and Medicine / 77

Salesian Journal of Humanities and Social Sciences, Vol. X, No. 2 (Dec 2019)

ISSN: 0976-1861 | 10.51818/SJHSS.10.2019.71-81 | Page: 71-81,

Section: Articles

Medicine by making the body subservient to the self-indulgence and negligence further weakens the mind preventing its escape from the vices that otherwise could have been transcended in its absence. In Hind Swaraj Gandhi constantly reminded the reader that the cause of diseases as to be negligence, indulgence and the doctors, medicine and hospitals - as an institution propagates this 'sin' of indulgence. Medicine significantly diminishes the prospects for self-reflexivity and traps the body and the mind into a chain of illness and cure. For Gandhi good health meant control over bodily desires as he writes:

Men take less care of their bodies and immorality increases...European doctors are worst of all...They practice vivisection....Most of their medical preparations contain either animal fat or spurious liquors...The fact remains that the doctors induce us to indulge in what we like, and the result is that we have become deprived of self-control and have become effeminate. In these circumstances, we are unfit to serve the country. To study European medicine is to deepen our slavery. ${ }^{18}$

Medical profession for Gandhi in Hind Swaraj is a spectacle of immorality run by a group of imposters and a competition for prestige and wealth among the professionals resulting in the impoverishment of humanity.

He further writes:

The population, in its credulity and in the hope of ridding itself of some diseases, allows itself to be cheated. Are not quacks then whom we know, better than the doctors who put on an air of humaneness. ${ }^{19}$

In An Autobiography Gandhi reiterated that one way to practice simplicity of life is to gradually de-colonize oneself from medicines. However, this does not qualify to categorize Gandhi as anti-modern but emphasis should be on his 'qualitative' denunciation. He did not altogether reject medicine. There were instances where he in fact acknowledged the help received from doctors to fight occasional illnesses. He writes:

\footnotetext{
${ }^{18}$ Gandhi, Hind Swaraj, 78-9.

${ }^{19}$ Gandhi, Hind Swaraj, 79.
} 


\section{8 / Bikash Sarma}

Salesian Journal of Humanities and Social Sciences, Vol. X, No. 2 (Dec 2019)

ISSN: 0976-1861 | 10.51818/SJHSS.10.2019.71-81 | Page: 71-81,

Section: Articles

While practicing in Durban, I suffered for sometime from debility and rheumatic inflammation. Dr. P.J. Mehta, who came to see me gave some treatment, and I got well...I kept myself fit with occasional laxatives and well regulated diet. But I could hardly call myself healthy, and always wondered when I should get myself free from the incubus of these laxative medicines. ${ }^{20}$

Subsequently, as an alternative Gandhi drew inspiration from 'No Breakfast Association' in Manchester of not taking the breakfast as that constituted overeating for him and to subsequently return to earth treatment. Gandhi's search for alternative cautiously evaded dichotomy of the west and the east as his learning through experiences were qualitatively drawn from both the contexts on the condition of not letting these experiences to lose self-control. As he contends:

He who runs to the doctor, vaidya or hakim for very little ailment, and swallows all kinds of vegetable and mineral drugs, not only curtails his life, but, by becoming the slave of his body instead of remaining its master, loses self-control... ${ }^{21}$

Though Gandhi was influenced by movements and the works mentioned above that rejected conformism to modernity and its universalist tendencies on the one hand, and advocated a 'regression' to nature on the other, he was not hostile to modernity wholeheartedly but was constantly in open dialogue with it. Though these often led to ambivalences but Gandhi thought it to be the way to incorporate one's learning and experiences in the journey for truth. For Gandhi process of learning should be interwoven with the course of life, guided by principles rather than some external authority. One reference point would be his encounter with one Dr. Kanuga in the extreme case of sickness Gandhi was undergoing. He narrates:

Dr. Kanuga came and pleaded with me to take medicine. I declined. He offered to give me an injection. I declined that too. My ignorance about injections was in those days quite ridiculous. I believed that an injection

\footnotetext{
${ }^{20}$ Gandhi, An Autobiography, 244.

${ }^{21}$ Gandhi, An Autobiography, 245.
} 
Gandhi in the Tropics: Climate, Disease and Medicine / 79

Salesian Journal of Humanities and Social Sciences, Vol. X, No. 2 (Dec 2019)

ISSN: 0976-1861 | 10.51818/SJHSS.10.2019.71-81 | Page: 71-81,

Section: Articles

must be some kind of serum. Later I discovered that the injection that the doctor suggested was a vegetable substance, but the discovery was too late to be put to use..$^{22}$

\section{Gandhi's dialogue with Medicine and its Variants}

If Gandhi's qualitative denunciation of western medicine rests on its colonization of the mind through colonizing the body his critique of indigenous medicine was based on its supposed anachronism. In the same speech, whereby through the metaphor of deadly knife he expressed his desire to resist the colonization of the soul propagated by western medicine he cautioned the audience about the current state of indigenous medicine:

I have hitherto confined my remarks to medicine and surgery in general, but when I come to Ayurvedic and Unani systems, I am filled with greater doubts...There was a time when I used to swear by the Ayurvedic medicine and used to commend it to all my friends, who went in for Western medicine, to go to these Ayurvedic physicians. But I feel sorry to have to own to you that I was deceived and I found that our Ayurvedic and Unani physicians lack sanity. They lack humility. Instead of that I found in them an arrogance that they knew everything, that there was no disease which they could not cure. I found that they believed that the mere feeling of the pulse could enable them to understand whether the patient was suffering from appendicitis or some such other disease. When I found that their diagnosis was false, that it was incomplete in most cases, I felt that it was nothing short of humbug. ${ }^{23}$

Gandhi's submission to the Ashtanga Ayurveda Vidyalaya, Calcutta where he was delivering the speech on the occasion of foundation-stone laying ceremony in 1925 was to improve the soul what he thought to be 'imperishable'. As he spoke:

May this institution take care not merely of the need of the body but of the imperishable soul that resides in the body. May it never be said of this

${ }^{22}$ Gandhi, An Autobiography, 401.

${ }^{23}$ Gandhi, Collected Works of Mahatma Gandhi, Vol 27, (Ahmedabad: Navjivan Trust, 1968), 45. 


\section{0 / Bikash Sarma}

Salesian Journal of Humanities and Social Sciences, Vol. X, No. 2 (Dec 2019) ISSN: 0976-1861 | 10.51818/SJHSS.10.2019.71-81 | Page: 71-81,

Section: Articles

institution that it panders to the basest taste of humanity, that it panders to the basest taste of the youths of Bengal...I know how their fair life is being shaped by the medicines that are poured down their throats by physicians... ${ }^{24}$

As Gandhi understood it, all variants of medicine and its practitioners have not analyzed the mind but emphasized more on the body - the changes occurring to the body as the basis of their diagnosis. As against external remedies Gandhi's concern was prevention of diseases through controlling the mind and senses. According to him this method of prevention and discoveries has been long forgotten and the challenge as Gandhi put it is to revive these great discoveries:

If the modern vaids and hakims kept in mind the atman while examining physical ailments, the body would, I am sure, revive the method of treating the mind rather than apply external remedies. Instead of polluting the body by injecting all sorts of serums, which are in fact forms of infection, they would be ready to explain natural laws... ${ }^{25}$

Vaids themselves have to 'acquire honesty of purpose' and discover methods and medicines to earn merits - spiritual rather and material. However, qualitatively appreciating the 'research spirit' of the west but at the same time denouncing the greed western medicine is perpetuating writes:

Today the vaids are intent on demanding a rupee for service worth a pie; they have nothing of the research spirit of the West, but imitate the West's

greed for money, learn by rote old verses and dispense medicines and add to the number of diseases instead of reducing it. ${ }^{26}$

\section{Conclusion}

Gandhi's views on medicine should be understood as a part of the discourse on modernity and asymmetrical relation between the east and the west

\footnotetext{
${ }^{24}$ Ibid, 45-6.

${ }^{25}$ Gandhi, Collected Works, vol. 24, 324.

${ }^{26} \mathrm{Ibid}, 544$.
} 
Gandhi in the Tropics: Climate, Disease and Medicine / 81 Salesian Journal of Humanities and Social Sciences, Vol. X, No. 2 (Dec 2019) ISSN: 0976-1861 | 10.51818/SJHSS.10.2019.71-81 | Page: 71-81, Section: Articles

that transpired at the contact zone. It came as a reaction to the genealogy of colonial medicine, moral hygiene, and population enumeration and control. Gandhi's experientialist understanding on medicine is rooted in the discourse on colonialism and nationalism and the allegory of the mind and body dualism. As the paper argues control over the body and mind via the discourse on medicine is experienced and expressed as the site of contestation between the colonizer and the colonized. 